\title{
A TRAJETÓRIA DO BANCO DO BRASIL NO PERÍODO RECENTE, 2001-2006: BANCO PÚBLICO OU BANCO ESTATAL "PRIVADO"?*
}

\author{
Rogerio Pereira de Andrade ${ }^{* *}$
}

Simone Deos ${ }^{* * *}$

RESUMO O objetivo deste texto é avaliar a performance do Banco do Brasil (BB) no período 2001-2006, enfatizando os seguintes aspectos: O desempenho do BB correspondeu ao de um banco público tradicional que atua como um importante instrumento de governo para a promoção do desenvolvimento? Ou, ao invés disso, a trajetória recente do banco pode ser caracterizada pelo reforço de uma lógica privada de atuação? O texto procura levantar algumas questões relativas ao papel do Estado na atividade econômica, particularmente o papel que um grande banco estatal pode e deve ter para financiar o desenvolvimento em um país periférico (e desigual) como o Brasil. A conclusão mais geral é que, desde meados dos anos 1980, o Banco do Brasil tem perdido crescentemente a função básica que costumava exercer como banco público.

Palavras-chave: Banco do Brasil; bancos públicos; setor público; sistema financeiro; regulação bancária

Código JEL: G20; H1; H8; N26

\footnotetext{
* Artigo recebido em $1^{\circ}$ de abril de 2008 e aprovado em 24 de novembro de 2008.

** Professor do Instituto de Economia (Unicamp), e-mail: roger.andrade@uol.com.br

*** Professora do Instituto de Economia (Unicamp), e-mail: simonedd@uol.com.br
} 


\section{THE RECENT PATH OF THE BANK OF BRAZIL, 2001-2006: PUBLIC BANK OR "PRIVATE" STATE-OWNED BANK?}

ABSTRACT The purpose of this paper is to assess the performance of the Bank of Brazil (BB) in the 2001-2006 period, with a focus on the following aspects: has the BB actually performed the role of a typical public bank, functioning as an important instrument to foster development in Brazil? Or, instead, has its recent path been characterised by the reinforcement of a private logic of behaviour? The paper aims at raising a few questions regarding the role of the state in the economic activity, particularly the role that a big state-owned bank can and must perform to finance development in a peripheral (and unequal) country like Brazil. The general conclusion is that, since the mid-80s, the BB has increasingly lost the key function that it formerly exerted as a public bank. A distinct pattern of behaviour has emerged, characterised by the bank's transformation into a "more private, less public" institution.

Key words: bank of Brazil; state-owned banks; public sector; financial system; banking regulation 


\section{INTRODUÇÃO}

Em virtude de seu caráter dual (ou híbrido), o Banco do Brasil (BB) tem se defrontado com o seguinte dilema: de um lado, sua atuação resulta de injunções que se dão no âmbito da dimensão da racionalidade empresarial privada; de outro, é a dimensão instrumental pública (agente executor de diretrizes de política econômica e/ou de políticas públicas em geral) que rege sua atuação. A tensão entre esses dois vetores imprime um determinado comportamento ou trajetória ao Banco. É justamente a co-habitação dessas duas forças, ora complementares, ora contraditórias, que define sua trajetória e condiciona sua situação atual.

O Banco do Brasil surgiu em 1905, quando uma crise bancária levou seu antecessor, o Banco da República do Brasil, à iminência de uma quebra. Devido à posição central que esta instituição ocupava no sistema financeiro nacional e ao seu papel "semioficial" de banqueiro do governo, o Tesouro Federal interveio para socorrê-lo. O "novo" banco que surgiu desse movimento foi chamado de Banco do Brasil, ficando sob controle direto da União. ${ }^{1} \mathrm{O}$ Tesouro comprou cerca de um terço das ações da nova instituição. Os novos estatutos do Banco autorizavam o Presidente da República a nomear o presidente e quatro diretores do Banco do Brasil.

À época, o governo federal tinha grande influência sobre o BB. Apesar de o Tesouro tornar-se acionista majoritário somente em 1923, quando comprou ações adicionais, o Banco atuava como uma instituição governamental desde 1905. E quando, em 1923, o governo federal assumiu o controle sobre o capital da instituição, fê-lo com o objetivo de usá-lo para estabilizar a taxa de câmbio. O BB tornou-se o único agente do governo em transações com moeda estrangeira.

Em março de 1942, os estatutos do BB — já à época a mais importante instituição de crédito funcionando no país - foram reformulados para adequarem-se à nova Lei das Sociedades Anônimas. Tal reformulação consagrou sua ação como autoridade monetária — pois o banco, por exemplo, garantia liquidez ao sistema bancário e constituía peça importante para a execução da política monetária - $e$ banco comercial.

A Lei da Reforma Bancária de 1964 (Lei no 4.595), entre outras determinações, criou o Banco Central e atribuiu a este funções antes exercidas pelo Banco do Brasil e pela Sumoc (Superintendência da Moeda e do Crédito), 
tais como emissão de moeda, controle do redesconto e das reservas obrigatórias. Contudo, a Lei no 4.595 definiu um modelo institucional para o BB que conservou seu caráter híbrido, pois continuou exercendo funções próximas à de autoridade monetária, ao mesmo tempo em que atuava como banco de fomento e banco comercial (HBB, 2007).

O objetivo deste trabalho é analisar a trajetória recente (2001-2006) do Banco do Brasil, a maior instituição financeira do país. ${ }^{2}$ Nossa hipótese de trabalho é de que há, a partir de 2001, um reforço e uma explicitação da dimensão empresarial privada do Banco, o que permitiria defini-lo, no referido período, menos como um banco público, e mais como um banco estatal. Isto é, o BB continua sendo uma entidade híbrida, mas diferente do que foi no passado relativamente recente. A diferença é que a lógica de atuação definese, no presente, preponderantemente nos mesmos termos de um banco privado típico, embora o controle acionário dessa instituição financeira pertença majoritariamente ao Estado brasileiro ${ }^{3}$ e (ainda) persistam programas e ações de natureza pública.

\section{ASPECTOS METODOLÓGICOS E INSTITUCIONAIS:}

\section{UMA PROPOSTA DE DELIMITAÇÃO CONCEITUAL DOS BANCOS PÚBLICOS}

O objetivo desta seção é tentar organizar uma metodologia de análise que possibilite uma compreensão mais adequada da natureza da atuação do BB em seu formato atual. Para tal, propõe-se como ponto de partida a tentativa de fundamentar alguns conceitos que serão úteis no decorrer da análise: $o$ de banco público e o de banco estatal.

\section{Conceito de banco público}

Um banco público pode ser caracterizado como uma instituição cujo controle acionário pertence geralmente ao Estado e que se caracteriza por desempenhar, preponderantemente, uma ou mais das seguintes atividades, sendo muitas delas inter-relacionadas:

- prover linhas de fomento e de crédito de longo prazo para segmentos que são eleitos como politicamente prioritários e que não são atendidos pelos bancos privados, tendo, em geral, como base para tal ação, um funding diferenciado; 
- definir novos produtos e/ou novos custos e prazos para produtos já existentes, de forma a induzir o mercado a atuar sob novas bases isto é, fazendo política de financiamento no sentido mais amplo da expressão;

- regular mais amplamente o mercado, sendo um canal privilegiado para transmitir os impactos das decisões tomadas no âmbito das políticas monetária e creditícia;

- exercer, no mercado de crédito, ações que minimizem a incerteza em momentos em que esta está exacerbada, uma vez que nessas circunstâncias há um "encolhimento" natural e defensivo do crédito por parte do sistema privado.

Historicamente, instituições financeiras foram criadas pelo Estado para fornecer as modalidades de crédito que as instituições financeiras privadas não têm interesse em prover. Uma razão para as instituições financeiras privadas (que captam recursos no mercado) não ofertarem uma categoria particular de serviço financeiro, ou fazer um empréstimo, é evidente: as taxas esperadas de default são elevadas — e, a uma taxa de juros alta o suficiente para "cobrir" esses defaults, o empréstimo pode tornar-se simplesmente inviável. Assim, uma justificativa para a operação de um banco público é a de que este, mais do que agir para corrigir supostas "falhas de mercado", procuraria estruturar aqueles mercados onde o setor privado reluta em atuar, sendo assim uma peça central para os objetivos e as estratégias de política pública.

Um banco público como banco de fomento é aquela instituição que provê linhas de fomento e de crédito de longo prazo, atendendo segmentos e setores em condições diferenciadas das que os agentes financeiros privados oferecem de forma voluntária e não dirigida, e que, para fazê-lo, conta não só com recursos próprios e recursos captados no mercado, mas também, e principalmente, com recursos fiscais e parafiscais de custo relativamente mais baixo. ${ }^{4} \mathrm{O}$ direcionamento do crédito é, pois, um aspecto importante de sua atuação. Nessa modalidade típica de banco público, que é a de ser banco de fomento, a instituição está atrelada a uma determinada orientação de política econômica ou de política pública em geral, voltada explicitamente à promoção de desenvolvimento socioeconômico, tendo em vista a escolha de determinadas políticas setoriais e/ou sociais. 
Nessa dimensão instrumental, não só como banco de fomento, mas também como um indutor de novas ações do mercado, é o agente financeiro executor par excellence de diretrizes de políticas governamentais. Nessa dimensão, a preocupação com retornos sociais, mais difíceis de serem mensurados, sobrepõe-se à preocupação com retornos privados dos projetos de investimento que a instituição venha a financiar, e mesmo com o retorno para a instituição bancária ao fazer aquela operação de crédito. Na verdade, o bom desempenho do banco como agente de fomento e como indutor de novos rumos para o mercado pode estar, e muitas vezes deve estar, em oposição ao desempenho financeiro do próprio banco.

Também cabe apontar o papel dos bancos públicos como agentes que cumprem uma função importante para a execução das políticas monetária e creditícia, definidas pela autoridade monetária. Vale dizer, pode e deve um banco público, exercendo seu poder no mercado creditício, "forçar" o mercado a seguir mais rapidamente os rumos das políticas monetária e (eventualmente) creditícia, quaisquer que sejam estes, contribuindo para a sua maior eficácia. Nesse sentido, sua dimensão pública, de regular e direcionar os mercados, pode estar também em conflito com sua dimensão privada voltada basicamente à maximização do lucro. ${ }^{5}$

Outro aspecto importante nesta discussão diz respeito à natureza do cálculo prospectivo capitalista, que se caracteriza pela formulação de expectativas em ambiente de incerteza genuína ou fundamental, o que tende a gerar fases de maior ou menor instabilidade no interior do sistema econômico. Sob essas condições, a ação reguladora de um banco público (no bojo de políticas públicas que definiriam objetivos estratégicos) teria como papel tentar contornar, ou minimizar, a incerteza que afeta inexoravelmente os processos econômicos. Seu objetivo deveria ser, portanto, o de "to defeat the dark forces of time and ignorance which envelop our future" (Keynes, 1936, p. 155). Nas conjunturas em que os bancos privados são mais avessos à incerteza, os bancos públicos tentariam minimizá-la ou arrefecê-la, atuando em áreas (e sob condições distintas da oferta privada de crédito) onde o setor privado, por diversas razões, não atuaria, se seguisse apenas sua lógica típica. ${ }^{6}$

\section{Conceito de banco estatal}

Sugere-se aqui a criação de uma categoria analítica que permita uma diferenciação crucial em relação à anterior. Assim, um banco estatal poderia ser 
definido como uma instituição financeira híbrida, em que, de um lado, a lógica de atuação predominante é aquela típica de um banco privado, mas que, de outro, o controle acionário permanece nas mãos do Estado. A busca e o cumprimento de objetivos definidos no âmbito das políticas públicas, quando ocorrem, dão-se de forma coadjuvante, secundária e subordinada a uma gestão empresarial privada.

Nesse caso, o foco predominante de atuação privilegiaria objetivos, metas e processos associados à rationale típica da atividade empresarial privada: geração máxima de lucros, otimização de receitas, retorno para os acionistas etc.

Ressalte-se, ainda, que essa atuação não decorre de um processo de descolamento ou "autonomização" em relação à orientação governamental, mas, sim, de uma nova abordagem, gerada no âmbito do próprio processo de formulação de políticas governamentais, que passa a informar o novo padrão de atuação da instituição financeira e que conta com a "cooperação" das próprias estruturas da instituição. A preocupação com os retornos privados tende a se sobrepor às diretrizes e orientações (ou falta de) das políticas governamentais centradas em retornos sociais, e mesmo às políticas de regulação e financeiras.

Nesse sentido, a ideia aqui é chamar a atenção para o fato de que, deixado ao seu bel-prazer, isto é, conferindo-lhe maior autonomia para definir seus objetivos e estratégias, descolado de políticas governamentais mais amplas voltadas à promoção do desenvolvimento socioeconômico, o banco público tende a se tornar cada vez mais banco estatal "privado".

\section{O PERÍODO 1986-1994: REFORMAS INSTITUCIONAIS, CONGLOMERAÇÃO, FRAGILIZAÇÃO FINANCEIRA E DETERIORAÇÃO PATRIMONIAL}

O objetivo desta seção é recuperar, em linhas gerais, os principais eventos e processos na trajetória do BB no período 1986-1994, que acabaram por condicionar alguns dos desdobramentos do período após o Plano Real. Esse período caracterizou-se por uma revisão do modelo de financiamento (funding) do BB, bem como de seu papel dentro do sistema financeiro nacional (Vidotto, 2002, cap. 10, e Jung, 2004, p. 99-115). 
Em 1986, no contexto das reformas que acompanharam o Plano Cruzado, tem lugar um aprofundamento do processo de reestruturação das finanças públicas brasileiras. A principal alegação era a necessidade de unificar e tornar mais transparente o processo orçamentário. O objetivo da unificação orçamentária era mitigar a confusão decorrente da existência dos diversos orçamentos e, consequentemente, controlar de forma mais eficiente as despesas públicas. No que diz respeito ao Banco do Brasil, introduziram-se alterações fundamentais no seu relacionamento com o Banco Central e o Tesouro Nacional. Dentre as várias medidas adotadas, a que causou impacto mais significativo sobre o BB foi o congelamento do saldo e posterior extinção da chamada "conta-movimento." Com isso, o BB sofreu o golpe fatal em seu papel de autoridade monetária. Em contrapartida, foi autorizado a praticar todas as operações permitidas às demais instituições financeiras.

A nova conjuntura afetou fortemente o Banco, obrigando-o a buscar novas formas de funding para a cobertura de suas posições ativas. Nesse contexto institucional, o mecanismo da conta-movimento foi substituído, de um lado, por uma sistemática de aporte de recursos do Tesouro, que desde o primeiro momento revelou-se errática, o que trouxe implicações sérias para o Banco, e, de outro, por captação própria junto ao mercado. ${ }^{7}$ É nesse sentido que, após 1986, as contas do Banco ficaram marcadas por uma inconsistência fatal: as operações ativas encontravam-se sob forte influência da política econômica e as operações passivas crescentemente sujeitas às condições de mercado. ${ }^{8}$

Com a Constituição Federal de 1988, uma mudança igualmente importante teve lugar. Transferiu-se do Banco Central para a Secretaria do Tesouro Nacional a gestão de fundos e programas governamentais. A consequência disso foi a retirada do BB da função de caixa do Tesouro, o que dificultou ainda mais o acesso a recursos não remunerados. Vidotto (1995, p. 62) avalia que a perda real de recursos decorrente dessa medida ficou próxima à perda decorrente do fim da conta-movimento (cerca de US\$ 7 bilhões).

Este processo pode ser sintetizado a partir de seus impactos sobre as operações passivas e ativas do Banco. No que diz respeito aos impactos sobre o funding, deve-se mencionar o fim da conta-movimento, a retirada dos depósitos à vista de várias instâncias de governo e a diminuição dos repasses do Tesouro Nacional. Quanto às operações ativas, vale destacar os refinancia- 
mentos e alongamentos (favorecendo principalmente os produtores rurais) de dívidas que agravaram as condições financeiras do Banco. O resultado foi um crescente descasamento dos prazos e custos entre captações e aplicações (Vidotto, 2002, p. 285-286).

Em decorrência da nova conjuntura de diminuição dos recursos que tipicamente davam suporte à sua atuação como banco de fomento, bem como da necessidade de responder à crescente fragilização financeira, o BB efetivou um processo de conglomeração (ver Jung, 2004, p. 107 e segs.). Tal movimento de conglomeração deu-se com a criação de diversas subsidiárias do banco comercial, que atuavam em vários segmentos do mercado financeiro, como a BB Distribuidora de Títulos e Valores Mobiliários S. A., a BB Financeira S. A., a BB Corretora de Seguros e Administradora de Bens S. A., a BB Administradora de Cartões de Crédito e o BB Banco de Investimentos S. A.

A conglomeração foi uma tentativa de responder e contornar a crise na qual a instituição se via imersa, que se projetava naquelas dimensões típicas de sua natureza dual, isto é, tanto no que diz respeito a ser um instrumento de política pública (mais especificamente, quanto um agente governamental de crédito) como no que toca à sua inserção mais explícita no plano da concorrência com os demais bancos, mas com o agravante de ter de lidar com uma progressiva deterioração patrimonial. Olhando à distância, é possível constatar que a conglomeração foi o primeiro round do processo de reorientação da instituição, ${ }^{9}$ com maior ênfase na lógica típica dos bancos privados, o que significou o início do aprendizado de capacidades e recursos necessários para levar a cabo um processo efetivo de conglomeração, que somente iria se consolidar mais adiante, na década de 1990. Esse período pode ser caracterizado como aquele em que o banco "abre a picada" em meio a uma mata espessa e ainda desconhecida.

No ano 1990, em decorrência de mudanças institucionais promovidas pelo Plano Collor, o Banco teve de lidar com novas situações, como o fim da Carteira de Comércio Exterior do Banco do Brasil (Cacex) ${ }^{10}$ e a transferência de suas funções para o então Ministério da Economia. Nesse mesmo ano, o BB passou por uma reformulação administrativa: sua estrutura organizacional foi alterada e o número de funcionários reduzido em cerca de $10 \%$ (HBB, 2007). 
Por sua vez, as condições de acesso ao funding, para exercer suas atividades de fomento, foram se tornando cada vez mais problemáticas. O volume de recursos aportado pelo Tesouro ao crédito agrícola representava, em 1991, apenas 17\% do total, obrigando o Banco a captar recursos em outras fontes. Além disso, a necessidade de controle da inflação tendeu a depreciar os preços mínimos dos produtos agrícolas, ao passo que os altos juros reais aumentavam os custos dos financiamentos, gerando descompassos com sérias repercussões nas atividades do banco. As mudanças ocorridas refletiram-se na estrutura patrimonial da instituição: enquanto, em 1985, apenas $34 \%$ das operações de crédito com o setor privado tinham como funding operações de mercado, ao final de 1994 essa proporção subiu para 80\% (HBB, 2007).

Assim, de meados da década de 1980 até meados dos anos 1990, houve uma queda progressiva dos recursos de origem fiscal no funding do $\mathrm{BB}$, e também de outros passivos não onerosos, ou pouco onerosos. Por outro lado, paradoxalmente, nesse mesmo período a instituição foi convocada para tentar resolver a crise fiscal e financeira do estado brasileiro e "socializar prejuízos". ${ }^{11}$ Como afirma Jung (2004, p. 115-116), "o Banco do Brasil continuou sendo exigido pelo governo e pela sociedade para o exercício de funções de cunho eminentemente público, que não se alinhavam com a racionalidade empresarial". Esse período foi também marcado por forte influência política de interesses corporativos (principalmente lobbies dos produtores rurais), que se traduziram em proteção financeira a certos setores.

Esse foi o período em que o Banco entrou em crise e começou a ensaiar alternativas. A trajetória de formação do conglomerado BB foi marcada, portanto, por peculiaridades próprias de uma instituição financeira cuja atuação dava-se no seio de um processo de revisão do papel do Estado na esfera econômica:

o propósito de imprimir um caráter eminentemente privado a sua gestão corrente e a todo o processo de expansão e diversificação da estatal financeira acaba encontrando limites estruturais que remetem à precedência ocupada por sua lógica de empresa pública. Em outras palavras, a mesma ordem de determinações que preside a formação do conglomerado também estabelece o horizonte de seu desdobramento (Vidotto, 2002, p. 285).

O Plano Real, anunciado em $1^{\circ}$ de julho de 1994, teve impacto imediato sobre o Banco. A queda da inflação implicou a perda dos expressivos ganhos 
inflacionários, e a valorização do real em face do dólar gerou perdas adicionais, dada a estrutura de ativos e passivos do Banco naquela moeda. As novas condições de baixa inflação e aumento do nível de inadimplência levaram a uma crise no sistema financeiro, tornando clara a situação de insolvência de diversos bancos, tanto privados quanto públicos, entre os quais o Banco do Brasil, que detinha uma carteira de ativos com muitos problemas.

Na seção seguinte, examinaremos os principais eventos do período do imediato pós-Plano Real até a introdução do Programa de Fortalecimento das Instituições Financeiras Federais, em junho de 2001. Este último marcou uma inflexão crucial na trajetória do Banco do Brasil, que será devidamente avaliada mais adiante.

\section{O PERÍODO 1995-2001: CRISE E CAPITALIZAÇÃO, O BANCO DO BRASIL EM BUSCA DE UMA NOVA IDENTIDADE}

Do ponto de vista da reorientação do papel dos bancos públicos, e do Banco do Brasil em particular, algumas medidas tomadas pelo governo federal de 1993 a 1995 foram cruciais (Jung, 2004, p. 119-120). Essas medidas foram as seguintes:

(1) a criação do Comitê de Coordenação Gerencial das Instituições Financeiras Públicas (Comif), em 1993, no âmbito do Ministério da Fazenda, medida que expressaria a percepção, por parte do governo, da necessidade de coordenação e centralização das políticas das Instituições Financeiras Públicas Federais (IFPFs);

(2) o Plano de Curto Prazo, de 1994, que enfatizava a importância do sistema financeiro público e a necessidade de seu enquadramento para disciplinar os gastos governamentais;

(3) o Plano de Ação Imediata (PAI), de 1995, o qual, no que diz respeito aos bancos públicos, explicitava a necessidade de saneá-los e definir mais claramente seu papel;

(4) a Nota Técnica 020/1995, do Ministério da Fazenda.

Em particular, a Nota Técnica (NT) 020, de 1995, foi um documento de grande importância para o destino dos bancos federais, pois estabeleceu a política do governo para essas instituições, ainda que a implementação dessas diretrizes não tenha sido completa ou linear (Vidotto, 2002, p. 214, e Jung, 
2004, p. 120-121). Seu objetivo foi o de estabelecer as missões, estratégias, objetivos, parâmetros de ajustamento e linhas de ação dessas instituições:

as agências financeiras do governo federal, no contexto atual e no horizonte previsível, justificam-se como instrumentos para a execução de sua política creditícia e como agentes do Tesouro Nacional, complementarmente ao sistema financeiro, por segurança estratégica (Ministério da Fazenda, 1995, apud Vidotto, 2002, p. 215).

No que diz respeito mais especificamente ao Banco do Brasil, o documento afirma que este permaneceria com as seguintes características:

Conglomerado financeiro federal, com atribuições específicas de fomento agroindustrial, de fomento ao comércio exterior, de relacionamento com o mercado financeiro internacional e de principal agente financeiro do Tesouro Nacional (Ministério da Fazenda, 1995, apud Vidotto, 2002, p. 217).

Em relação a esse ponto, uma questão importante que se coloca diz respeito à reafirmação da permanência, em contexto aparentemente tão adverso, do setor público federal como participante direto e tão expressivo no Sistema Financeiro Nacional e, mais ainda, ao caráter dessa reafirmação. Se, por um lado, é verdade que as IFPFs não foram privatizadas, diferentemente dos bancos estaduais, e que tiveram, no plano do discurso, sua necessidade reafirmada, por outro lado também se percebe, nesse conjunto de movimentos que tem na NT uma de suas primeiras expressões, um encaminhamento dos bancos federais, e do BB em particular, crescentemente para a lógica típica de um banco privado, com prejuízo de sua ação pública. Nesse sentido, houve um abrandamento e atenuação de sua faceta de banco público, et pour cause, consequente fortalecimento da de banco estatal (nos termos do anteriormente definido). É como se, apesar de sua manutenção como propriedade do Estado, o espaço efetivo para a ação das políticas públicas se encurtasse, ganhando mais importância, de outro lado, a eficiência microeconômica da empresa e sua capacidade de gerar retornos para o acionista. ${ }^{12} \mathrm{O}$ enquadramento subsequente do Banco nas regras de Basileia I em 1994 e a perspectiva de seu futuro enquadramento nas normas de Basileia II (previsto para vigorar a partir de 2011), sob o pretexto de fortalecer a instituição e o Sistema Financeiro Nacional, configuram marcos nessa mesma trajetória, que se iniciou mais claramente em 1995. 
Outro acontecimento de importância capital em 1995 para a trajetória futura do Banco do Brasil foi seu expressivo prejuízo ( $\mathrm{R} \$ 4,88$ bilhões), basicamente atribuível aos resultados negativos da intermediação financeira ( $\mathrm{R}$ \$ 264,9 milhões) ${ }^{13}$ — vale dizer, ao alto grau de inadimplência da carteira de crédito. ${ }^{14}$ Nesse contexto, iniciaram-se as medidas saneadoras dentro do banco (Programa de Ajustes), visando à redução de despesas e ampliação de receitas.

Buscou-se aumentar receitas com a cobrança por serviços prestados, a ampliação do leque de produtos oferecidos e a exploração do potencial da rede de vendas. Em termos de redução de custos, entre 1995 e 1996, perseguiram-se a racionalização da rede de dependências — reduziu-se em 170 o número de agências - e a diminuição do número de funcionários em 34 mil, representando o rompimento do modelo de relações trabalhistas até então existente (HBB, 2007).

Contudo, os resultados foram insuficientes para resolver, a curto prazo, os problemas da instituição na magnitude em que se acumularam. Ademais, variáveis conjunturais, como o recrudescimento da inadimplência e a valorização do real em face do dólar, contrabalançavam o esforço do ajuste.

No ano 1996, os prejuízos foram ainda maiores (R \$ 8,22 bilhões), resultantes, basicamente, do desempenho negativo da intermediação financeira ( $\mathrm{R} \$ 2,79$ bilhões). É inegável que havia a necessidade de reconhecer créditos em default e explicitar seu impacto nos demonstrativos contábeis. Todavia, o reconhecimento das perdas, na elevada magnitude em que ocorreu, pode ser explicado, em boa medida, por uma política conservadora de aprovisionamento de crédito e pelo "endurecimento" das negociações do Banco com seus devedores, sobretudo na área agrícola (conforme Jung, 2004, p. 127128, e Vidotto, 2002, p. 293-294).

Dado que o Patrimônio Líquido do Banco, ao final de 1995, era de $\mathrm{R}$ \$ 3,97 bilhões, e que o resultado do ano 1996 foi um prejuízo de $\mathrm{R} \$ 8,22$ bilhões, o Banco teria "quebrado" nesse ano, se não tivesse passado por uma capitalização. A capitalização teve a seguinte composição: emissão de novas ações no valor de R 8 bilhões, sendo R \$ 6,4 bilhões adquiridas pelo Tesouro Nacional, $\mathrm{R} \$ 500$ milhões pelo Bndespar e o restante ( $\mathrm{R} \$ 1,1$ bilhão) pelo Fundo de Previdência dos Funcionários do Banco do Brasil (Previ).${ }^{15}$ Em consequência, houve expressivo aumento da participação do Tesouro no 
capital total do Banco, que de cerca de 30\% passou a 73\%. A capitalização, na magnitude em que foi feita, equacionou os problemas patrimoniais da instituição. Ao mesmo tempo, disponibilizava-se ao Banco uma massa de créditos passíveis de recuperação no futuro. Como observa Jung:

A renegociação destes créditos viria a se mostrar de fundamental importância nos exercícios seguintes. Enquanto implantavam-se reformas de maturação mais lenta e de maior envergadura, foi a recuperação de créditos inadimplidos, viabilizadas pelos instrumentos de negociação disponibilizados pelo governo, que garantiram os resultados positivos do Banco. Estes instrumentos foram a securitização das operações, a partir de 1996, e a introdução do Programa Especial de Saneamento de Ativos em 1998. As medidas tinham em comum o alongamento do perfil das dívidas e a substituição dos instrumentos de crédito originais por títulos de emissão governamental de vencimento futuro. $\mathrm{O}$ devedor, além da responsabilidade de aquisição destes títulos, se responsabilizava pelo pagamento dos juros incidentes sobre os papéis (Jung, 2004, p. 128).

É importante salientar ainda que a capitalização promoveu a adequação do patrimônio líquido do Banco às exigências do Acordo da Basileia, adotado no Brasil em 1994, que estabelecia uma relação mínima de 8\% entre o capital da instituição e os ativos ponderados pelo seu risco, e que visava à melhoria da saúde e solidez do sistema bancário. ${ }^{16}$ Em 1995, o "Índice de Basileia" do Banco era 5,7\% (inferior, portanto, ao requerido) e, ao final de 1996, após a capitalização, alcançou 11,1\%.

A partir de 1997, o Banco passou a gerar lucro. A diferença mais marcante, no que diz respeito aos resultados em relação aos dois anos anteriores (1995 e 1996), encontra-se no resultado da intermediação financeira (resultado das operações de crédito), que se tornou positivo a partir de 1997, ao mesmo tempo em que é possível verificar uma importante tendência de queda na despesa com pessoal, resultado do Programa de Ajustes, do qual o Programa de Desligamento Voluntário foi peça fundamental. A despesa de pessoal caiu de R\$ 7,2 bilhões, em 1995, para R\$ 6,1 bilhões, em 2000.

A questão da qualidade e do perfil da carteira de crédito é central nessa discussão. Nesse contexto de reformas e reestruturações, para além da admissão dos “erros" do passado, que foram responsáveis pelo estoque de problemas que se procurava atacar, avaliava-se que o Banco não possuía competência para conceder crédito em um cenário futuro de estabilidade 
monetária. Apontava-se para a necessidade de novas práticas na área e, para tanto, estabeleceram-se as seguintes medidas: adoção do limite de crédito por cliente, segregação das funções de crédito e operacionais e decisão sobre concessão de crédito exclusivamente em regime colegiado. ${ }^{17}$

A concessão do crédito passou a ter como referência uma avaliação dos setores de acordo com o interesse "negocial" para o Banco. Tal avaliação é objeto de revisões periódicas, com a finalidade de revisar a política de crédito e, mais precisamente, os riscos e limites de exposição de crédito por cliente. Como aponta Jung (2004, p. 130-131):

O conjunto de medidas sinalizava a criação de uma cultura de crédito, distanciando-se dos critérios, até então preponderantes, de atendimento das demandas para atividades de fomento de setores ou empresas em dificuldades de acesso a crédito no mercado - neste sentido, exercendo a função de emprestador de penúltima instância.

Caminhou-se efetivamente para a criação de uma cultura de crédito muito similar àquela adotada pelos bancos privados, que tornou preponderante a valorização do capital, ponderado o risco, para o estabelecimento das condições gerais de crédito e realização de operações com clientes.

Vidotto (2002, p. 280-281) observa ainda que, na ausência de orientações advindas de uma política que coordenasse a ação dos bancos públicos, o próprio Banco elaborou suas regras de conduta, as quais provavelmente o aproximaria do perfil de atuação de uma instituição financeira privada típica.

Essa mudança na "cultura do crédito" no Banco do Brasil a partir desse período é enfatizada na literatura sobre o tema, sendo considerada uma das questões mais relevantes (Vidotto, 2002, p. 280; Oliveira, 2003, p. 47-49; Jung, 2004, p. 130-131). Os resultados positivos dos anos seguintes, que refletiram uma reversão dos prejuízos de 1995 e 1996, parecem confirmar a tese de que a gestão do crédito tornou-se mais "eficiente" a partir de tais mudanças de orientação.

Contudo, do nosso ponto de vista, uma questão crucial é avaliar se, nesse período, para além dos resultados do Banco do Brasil sob o ponto de vista de uma "massa de capital que busca sua valorização" e/ou de uma "fonte de geração de superávit primário para o seu controlador” (Oliveira, 2003, p. 45), o Banco continuou atuando como uma instituição central e estratégica na operação de políticas públicas. Em outras palavras, a indagação a ser 
feita é se o Banco do Brasil, que não só não foi privatizado como foi capitalizado, fortaleceu-se, de fato, como banco público, ou se apenas iniciou uma nova trajetória como banco estatal, devidamente fortalecido.

Para Oliveira (2003), que salienta a questão do crédito rural, a resposta é clara:

A partir de 1995, a gestão da carteira de crédito agrícola é submetida aos rigores da globalização financeira, por meio do ajuste fiscal e dos princípios de regulação prudencial ditados pelo Acordo de Basileia. A busca de rentabilidade mínima no crédito rural passa a ser determinante para a sobrevivência do Banco do Brasil. (...)

O crédito rural nos anos 1990 está submetido a duas grandes forças, que convergem para a preservação da reprodução dos capitais que interagem no agribusiness: (1) uma que reflete o poder decisório dos Complexos Agroindustriais na formulação da política agrícola, em face da crise do Estado, e (2) outra que busca a padronização da regulação bancária prudencial com vistas à preservação da estabilidade dos sistemas financeiros, nacional e internacional.

No encontro da nova dinâmica da agricultura brasileira com a globalização financeira, finca-se em 1995 um novo marco na história do crédito rural no Brasil. Esse marco é reforçado pela estratégia do Banco do Brasil de tornar-se mais moderno e competitivo (p. 13-14).

Oliveira (2003, p. 47) afirma, ainda, que fazer operações de crédito mais seguras e lucrativas — isto é, atuar como um banco comercial típico — tem um custo social nada desprezível (e pouco salientado). Especificamente no que tange à questão do crédito rural, essa nova estratégia agrava a exclusão de pequenos produtores e fortalece os grandes grupos que atuam no agribusiness. Assim, no decorrer da década de 1990, ao ser reorganizado para atuar como banco estatal, o Banco do Brasil pode ter contribuído, de alguma forma, para uma piora distributiva no setor agrícola. ${ }^{18}$

Vidotto (2002, p. 254) faz, também, algumas considerações sobre a reorientação do papel do Banco do Brasil:

Importa também identificar a mudança de conteúdo havida nesses dois subsistemas [de crédito oficial: o de crédito rural, do qual ao redor de dois terços são historicamente respondidos pelo BB, e o de financiamento habitacional, sob predomínio da $\mathrm{CEF}$. As novas condições impõem uma redução no seu alcance como instrumento de política econômica em dois sentidos. Um, sua 
diminuição como instrumento de socialização de prejuízos sob a forma de "hospital" de empresas ou setores cuja reconversão não apresenta horizonte econômico sustentável. A indústria e a agricultura fornecem diversos exemplos onde os bancos públicos abandonaram empresas ou todo um setor, assim como outros onde o retorno da cobertura se deu após um processo de seleção "selvagem". Equivale dizer, esses instrumentos tornaram-se de fato, em determinadas linhas de operação, mais seletivos e descomprometidos com a estrutura produtiva pregressa. Por outro lado, têm sido estruturadas novas linhas e programas que caminham na contramão daquele movimento.

As novas linhas e programas aos quais se refere esse autor nascem, segundo ele mesmo, "externamente" a esse redirecionamento das políticas e práticas de concessão de crédito. De um lado, isso incluiria as constantes renegociações das dívidas do setor rural, que foram reiteradamente "arrancadas", nas palavras do autor, pela "bancada ruralista", de tal sorte que, longe de constituir excepcionalidade, tal prática configuraria, isso sim, a lógica de relação do Banco com o setor. De outro lado, o autor aponta para a criação do Programa de Fortalecimento da Agricultura Familiar (Pronaf), em 1995, "cuja relevância decorre tanto dos valores envolvidos como de seu sentido de fomento dirigido aos produtores rurais de baixa renda" (Vidotto, 2002, p. 281). Assim, para Vidotto (2002), a despeito das grandes modificações no Banco do Brasil na década de 1990, ele ainda continuou como principal agente da política de crédito rural, proporcionando ao setor condições diferenciadas para a acumulação. ${ }^{19}$

No que diz respeito à composição do funding do $\mathrm{BB}$, houve queda da participação dos recursos do Tesouro Nacional no passivo (de 1,3\% em 1996 para 0,64\% em 2000), além de uma queda no total dos recursos oficiais em relação ao passivo total (de 7,95\% em 1996 para 6,74\% em 2000).

Quanto à participação do Banco no total das operações de crédito do sistema bancário, esta cai de 19,9\%, em 1994, para 16\%, em 1995, em virtude da mudança nos critérios de avaliação dos créditos problemáticos que resulta no aprovisionamento dos créditos inadimplidos. Em 1996, pelo mesmo motivo, continuou a cair, chegando a 10,6\% e permanecendo nesse patamar em 1997. O montante de operações de crédito do Banco em 1995 foi de $\mathrm{R} \$ 38,8$ bilhões, passando para o montante de $\mathrm{R} \$ 28$ bilhões no período 1996-1998, o que implicou um encolhimento expressivo da carteira. 
Apesar de uma discreta recuperação em 1998, o Banco do Brasil não recuperou posição até o final da década, fechando o ano 2000 como detentor de $11 \%$ do total das operações de crédito.

Ainda dentro do período em foco (1995-2001), uma questão importante é averiguar, novamente, o enquadramento do Banco do Brasil no chamado Índice da Basileia. Em 1997, o Banco Central do Brasil elevou os requerimentos de capital dos bancos atuantes no sistema financeiro nacional para $11 \%$, ou seja, para além dos $8 \%$ recomendados pelo Comitê da Basileia, que o próprio Banco Central exigira dos bancos entre 1994 a 1996. Com esse novo requerimento de capital, o Banco do Brasil viu-se insuficientemente enquadrado em 1997 (10,8\%), no limite em 1998 (11,1\%) e novamente desenquadrado em 1999 (9,2\%). É dentro desse contexto que se podem entender, especificamente para o caso do BB, o conteúdo do Programa de Fortalecimento das Instituições Financeiras Federais (MP no 2.196, de junho de 2001) e as mudanças cruciais que seguiram.

Tendo em vista as questões até aqui levantadas, uma possível conclusão geral sobre a ("aparente concepção privatista" da) gestão do BB na segunda metade dos anos 1990 é a seguinte:

[É] necessário distinguir nos três traços analisados na segunda metade da década de 1990 - evolução da estrutura de ativos, evolução do crédito e critérios de desempenho - as diretrizes de política econômica por trás da aparente concepção privatista da gestão do BB. Na recomposição dos ativos esse elemento é patente. Na reorientação creditícia, cujo conteúdo residiu no afastamento das atividades de menor rentabilidade em operações desempenhadas com funding de mercado, cumpre ressaltar que se deu na ausência de uma política industrial. Mesmo o ajuste administrativo, no qual essa concepção teve espaço para uma implementação mais profunda, apresenta um caráter ambíguo, na medida em que seu eventual êxito contribui para reforçar o alcance instrumental da instituição (Vidotto, 2002, p. 292).

[O] propósito de imprimir um caráter eminentemente privado à gestão dessa instituição, no primeiro governo Cardoso, acabou resvalando em limites estruturais, realçados pela instabilidade conjuntural interna e externa. Ou seja, a mesma ordem de determinações que presidiu o processo de expansão do conglomerado também restringiu o horizonte para seu desdobramento. O propósito de implantar uma reestruturação que preparasse o banco para a privatização chocou-se com a inadimplência e os prejuízos, a tentativa de ampliar a participação privada no capital fracassou e o esforço 
para privatizar uma das mais importantes empresas do conglomerado foi revertido. ${ }^{20}$

Nesta perspectiva, a capitalização de $\mathrm{R} \$ 8$ bilhões do Banco do Brasil, em 1996, adquire um sentido mais preciso. Ela constituiu o ápice de sucessivos movimentos que acompanharam o fim dos créditos largamente subsidiados à agricultura, após a extinção da conta-movimento em 1986, período em que a proteção creditícia do Estado à agricultura não desapareceu, mas ficou camuflada na crescente deterioração das contas do BB. Enfrentada a crise com a reestruturação patrimonial da estatal financeira, é como se a capitalização viesse a posteriori preencher a função da conta-movimento. Com a diferença de que, embora a natureza fiscal de tais recursos esteja mais bem explicitada, a definição das condições financeiras e dos montantes envolvidos permaneceu sujeita a processos incertos e precários (Vidotto, 2002, p. 300).

A lógica de atuação que vem a ser instaurada e consolidada no período posterior ajuda a lançar mais luz sobre essas questões.

\section{O PERÍODO 2001-2006: GOVERNANÇA CORPORATIVA SOB O ACORDO DE BASILEIA, PREDOMÍNIO DA LÓGICA EMPRESARIAL PRIVADA}

O Programa de Fortalecimento das Instituições Financeiras Federais (MP $\mathrm{n}^{\circ}$ 2.196, de 28.6.2001) procurou adequar os bancos controlados pelo governo federal a uma forma de regulamentação bancária semelhante à dos bancos privados. O Programa reconhecia que o objetivo dessa nova legislação era refletir "padrões internacionais estabelecidos pelo Acordo de Basileia". Essa legislação tornaria os bancos "mais fortes, mais competitivos e, sobretudo, mais transparentes", e alegava a necessidade de impor às IFPFs "a mesma disciplina a que estão submetidos os bancos privados" (Ministério da Fazenda, 2001).

A ênfase na lógica empresarial privada foi colocada no mesmo nível da suposta "missão institucional" de cada instituição:

Trata-se de assegurar que as instituições públicas federais estejam preparadas tanto para competir como bancos comerciais como também para desempenhar com eficiência sua missão de fomento ao desenvolvimento econômico e social dado que sua privatização neste governo é hipótese definitivamente afastada conforme já se manifestou publicamente o presidente Fernando Henrique Cardoso (Ministério da Fazenda, 2001). 
Do ponto de vista do Banco do Brasil, o Programa de Fortalecimento das Instituições Financeiras Federais representou a continuidade das medidas de saneamento e capitalização realizadas em 1995 e 1996. Essas medidas teriam como objetivo

o enquadramento contábil do Banco do Brasil ao índice de Basileia e ao cumprimento das exigências estabelecidas pelos órgãos fiscalizadores e reguladores das atividades bancária e financeira fortalecendo a estrutura de capital do Banco.

Os ajustes tornaram-se necessários em virtude do aprimoramento da regulação prudencial sobre as instituições financeiras que resultou dentre outras medidas na elevação do índice mínimo de adequação do capital (de 8\% para $11 \%$ ), no aumento do percentual de ponderação de risco sobre os créditos tributários (de $20 \%$ para $300 \%$ ) e na definição pela Resolução Bacen 2.682 de 1999 de novos critérios de classificação de risco de crédito e de novos níveis de provisão (Ministério da Fazenda, 2001).

As principais medidas buscavam transferir riscos de crédito para o Tesouro Nacional e trocar ativos de pouca liquidez e baixa remuneração por ativos líquidos remunerados à taxa de mercado. No caso específico do Banco do Brasil, esse Programa possibilitou o seguinte:

- redução dos ativos ponderados pelo risco em R $\$$ 6,98 bilhões;

- redução do Patrimônio Líquido Exigível (PLE) em R 768 milhões;

- aumento do Patrimônio de Referência (PR) em R\$ 2,81 bilhões. ${ }^{21}$

A implementação desse Programa trouxe uma consequência importante: o índice de Basileia, que em 2000 situava-se em 8,8\%, atingiu 12,7\% em 2001; a partir daí, continuou a subir, chegando a 15,2\% em 2004 e 17,3\% em 2006 (tabela 1). ${ }^{22}$

Para Vidotto (2002), o significado principal desse conjunto de medidas não é o que se apresenta oficialmente (assegurar a boa governança dos bancos públicos), mas, sim, o de ser um

vasto programa de estatização de prejuízos socializados através dos bancos federais ao longo de governos anteriores (...) fechando um ciclo sem que se tenha promovido um esforço oficial de identificação dos beneficiários e um debate mais profundo de seus impactos distributivos (Vidotto, 2002, p. 265).

Contudo, e sem descartar essa questão, nossa hipótese é a de que o significado principal do referido Programa foi o de, ao fortalecer a estrutura de 
Tabela 1: Índices de rentabilidade e produtividade e estrutura de capital, 2001-2006

\begin{tabular}{|c|c|c|c|c|c|c|}
\hline Índices (\%) & 2001 & 2002 & 2003 & 2004 & 2005 & 2006 \\
\hline \multicolumn{7}{|l|}{ Rentabilidade e Produtividade } \\
\hline RSPL' (Lucro Líq./Patr. Líq. (\%) & 12,4 & 22,0 & 19,6 & 21,4 & 24,7 & 29,1 \\
\hline Eficiência (Desp. Adm./Rec Operacionais (\%) & 69,2 & 59,0 & 56,3 & 58,2 & 86,1 & 53,4 \\
\hline Cobertura (RPS/Desp. de Pessoal (\%)2 & 67,4 & 80,3 & 80,6 & 93,1 & 102,3 & 112,9 \\
\hline \multicolumn{7}{|l|}{ Estrutura de Capital } \\
\hline Alavancagem $(x)$ & 18,6 & 22,2 & 18,9 & 16,9 & 15,0 & 14,3 \\
\hline Basileia (\%) & 12,7 & 12,2 & 13,7 & 15,2 & 17,1 & 17,3 \\
\hline
\end{tabular}

capital do Banco, aprofundar o movimento já percebido de aproximação do BB a uma gestão guiada pela lógica privada, em detrimento de sua ação pública e a despeito do aumento da participação do Tesouro em seu capital. Tal orientação foi feita sob o pretexto, aparentemente indiscutível, de enquadrar essa instituição — bem como as outras IFPFs — em um conjunto de regras internacionalmente aceitas e, em princípio, tecnicamente irrefutáveis, que teriam como objetivo levar os bancos a um melhor gerenciamento de risco. Ao fazê-lo, essas regras levariam o sistema bancário a um nível maior de segurança. A análise dos dados do período 2001-2006 contribui para corroborar nossa hipótese.

A tabela 1 apresenta a evolução dos índices de rentabilidade e produtividade. A rentabilidade sobre o patrimônio líquido do BB, que era de 12,4 \%, em 2001, passou para 29,1\%, em 2006. É também francamente positiva a evolução dos indicadores de eficiência e cobertura, sendo particularmente notável a evolução deste último, que expressa a relação entre receita de prestação de serviços relativamente às despesas de pessoal: de 67,4\%, em 2001, aumentou para $112,9 \%$ em 2006.

Outra evidência importante para avaliar o novo perfil do Banco é o comportamento do índice de Basileia. A tabela 1 mostra que, a partir de 2001, o BB está perfeitamente enquadrado às exigências de capitalização que o Banco Central impôs ao sistema financeiro nacional, tendo atingido, desse ponto de vista, os objetivos da MP no 2.196.

A tabela 2 apresenta as principais contas do balanço patrimonial do BB para o período 2001-2006. Ela mostra que houve, a partir de 2001, uma forte elevação do volume de operações de crédito do Banco (um aumento 


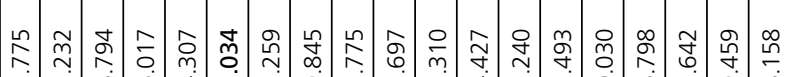

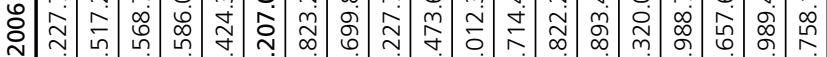
p)

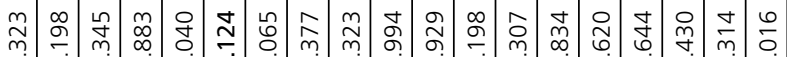

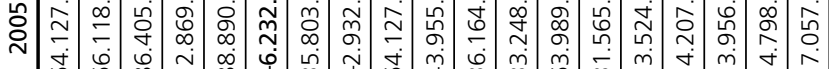

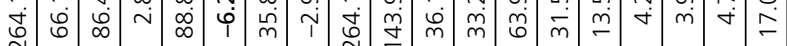

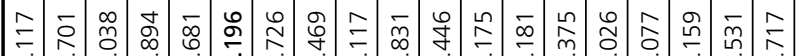

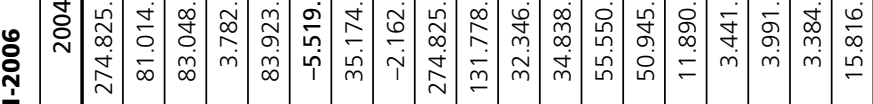

¿ุ̀

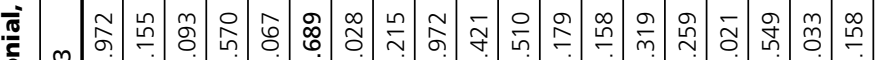

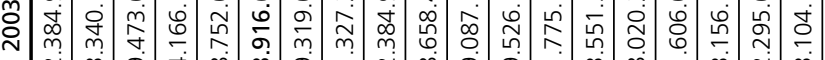

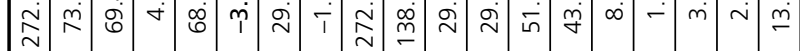

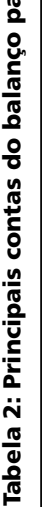

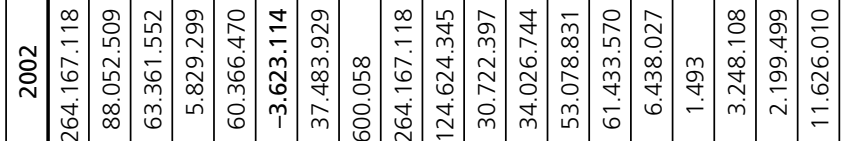

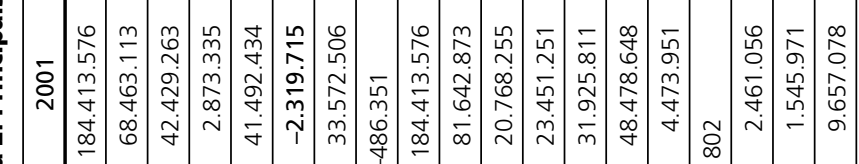

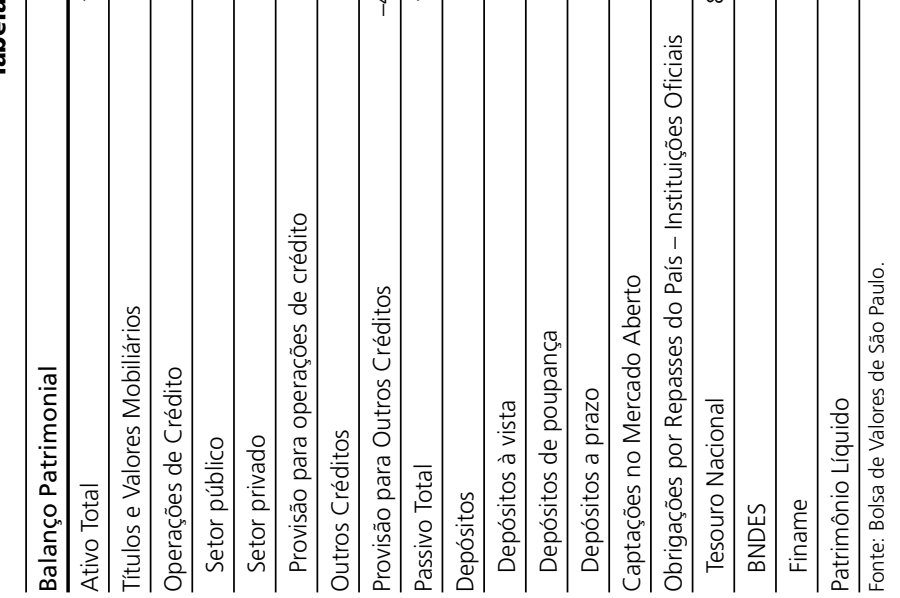


Tabela 3: Balanço patrimonial, análise vertical, 2001-2006 (percentual do ativo total)

\begin{tabular}{lrrrrrr}
\hline Balanço Patrimonial: Análise Vertical & 2001 & 2002 & 2003 & 2004 & 2005 & 2006 \\
\hline Títulos e Valores Mobiliários/Ativo Total & 37,12 & 33,33 & 26,93 & 29,48 & 25,03 & 23,59 \\
\hline Operações de Crédito/Ativo Total & 23,01 & 23,99 & 25,51 & 30,22 & 32,71 & 37,12 \\
\hline Operações de Crédito do Setor Público/Ativo Total & 1,56 & 2,21 & 1,53 & 1,38 & 1,09 & 1,18 \\
\hline Operações de Crédito do Setor Privado/Ativo Total & 22,50 & 22,85 & 25,24 & 30,54 & 33,65 & 38,40 \\
\hline
\end{tabular}

Fonte: Elaboração própria a partir da tabela 2.

de $156 \%$ no período), em virtude, basicamente, do crescimento no segmento de crédito ao setor privado. É possível identificar ainda que, em termos absolutos, a carteira de títulos e valores mobiliários apresentou oscilação durante o período. A mudança mais acentuada ocorreu de 2001 para 2002.

A tabela 3 explicita a alteração na posição relativa (em termos de percentual do ativo total) da carteira de títulos e valores mobiliários relativamente à carteira de crédito. No ano 2001, a carteira de títulos representava $37 \%$ do ativo. Contudo, ao longo do período houve uma queda contínua de sua participação, que em 2006 alcançou $23,6 \%$ do ativo. A carteira de crédito apresentou comportamento inverso, isto é, um crescimento contínuo no período, passando de 23\% do ativo, em 2001, para 37,1\%, em 2006.

Quanto à estrutura do funding, a tabela 2 mostra, para o período 20012006, um crescimento do repasse de recursos das instituições oficiais. Contudo, como se pode observar na tabela 4, esses recursos representaram, ao longo do período em tela, pequena parcela do passivo (de 2,4\%, em 2001, passaram para 4,7\%, em 2006). O que chama a atenção, no que diz respeito ao passivo, é o crescimento expressivo dos depósitos em termos absolutos e relativos (tabelas 2 e 4).

Por sua vez, os dados da tabela 5 mostram que entre os anos 2001 e 2006 houve um crescimento importante nas receitas da intermediação financeira, mas com muitas oscilações no interior do período. Tal comportamento decorreu, por seu turno, das flutuações nas receitas advindas das operações com títulos e valores mobiliários, uma vez que as receitas de operações de crédito apresentaram uma tendência mais consistente de crescimento. O resultado bruto da intermediação financeira mudou expressivamente de patamar de 2001 para 2002, quando houve um crescimento de mais de $100 \%$, permanecendo nesse novo patamar ao longo do período. O resultado operacional, por sua vez, apresentou uma tendência mais regular de eleva- 
Tabela 4: Balanço patrimonial, análise vertical, 2001-2006 (percentual do passivo total)

\begin{tabular}{lllllll}
\hline $\begin{array}{l}\text { Evolução dos Passivos: Análise Vertical } \\
\text { (Percentual do Passivo Total) }\end{array}$ & 2001 & 2002 & 2003 & 2004 & 2005 & 2006 \\
\hline Depósitos/Passivo Total & 44,27 & 47,18 & 50,91 & 47,95 & 54,50 & 53,25 \\
\hline Depósitos à Vista/Passivo Total & 11,26 & 11,63 & 10,68 & 11,77 & 13,69 & 13,20 \\
\hline Captações no Mercado Aberto/Passivo Total & 26,29 & 23,26 & 15,99 & 18,54 & 11,95 & 16,45 \\
\hline $\begin{array}{l}\text { Obrigações por Repasses do País - } \\
\text { Instituições Oficiais/Passivo Total }\end{array}$ & 2,43 & 2,44 & 2,94 & 4,33 & 5,12 & 4,72 \\
\hline Tesouro Nacional & 0,00 & 0,00 & 0,59 & 1,25 & 1,59 & 0,99 \\
\hline BNDES & 1,33 & 1,23 & 1,16 & 1,45 & 1,50 & 1,54 \\
\hline Finame & 0,84 & 0,83 & 0,84 & 1,23 & 1,82 & 1,98 \\
\hline
\end{tabular}

Fonte: Elaboração própria a partir da tabela 2.

ção no período. Contribuiu particularmente para tal a elevação nas receitas de prestação de serviços, que cresceram em pouco mais de $100 \%$ de 2001 para 2006. A mesma tabela 5 mostra o comportamento do resultado operacional no período, que apresentou forte crescimento.

A tabela 6 mostra, por seu turno, que o Banco recuperou, em 2003, a participação que detinha no total de operações de crédito concedidas pelos bancos no país em 1994 (antes, portanto, do ajuste de 1995-1996). O BB detinha, então, 19,9\% das operações de crédito da área bancária e, após recuperar-se dos percalços da década de 1990, quando registrou uma participação em torno de $10 \%$, passou a deter $20,4 \%$ em 2003 . Ao final do ano 2005, detinha 18,5\% das operações do sistema.

As evidências apresentadas até agora indicam que o Banco do Brasil teve performance excepcional, ao longo do período em tela, no que diz respeito ao incremento da produtividade, tal como medida convencionalmente, ${ }^{23} \mathrm{e}$ da rentabilidade.

Contudo, é necessário observar também indicadores e ações que digam respeito ao desempenho do BB como banco público - ação que desempenha, por exemplo, ao financiar amplamente o agronegócio, sendo sua carteira de crédito ao agronegócio a primeira do ranking das instituições integrantes do Sistema Nacional do Crédito Rural.

O crédito ao agronegócio cresceu cerca de $115 \%$ em quatro anos: ${ }^{24}$ passou de $\mathrm{R} \$ 21,3$ bilhões, em 2002, para R $\$ 45$ bilhões, em 2006, ${ }^{25}$ compondo $33,8 \%$ da carteira ao final deste ano, relativamente a uma participação de 26,7\% em 2002 (tabela 7). Esses números indicam um crescimento da car- 


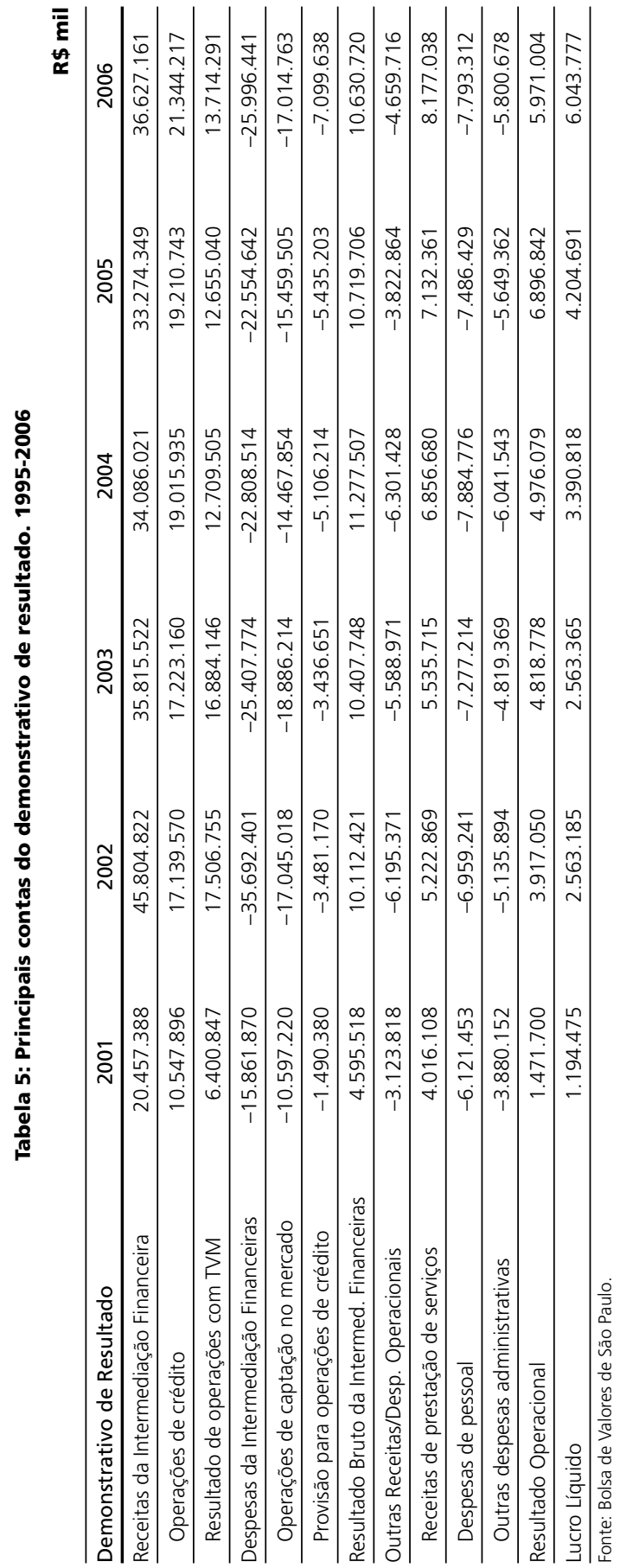


Tabela 6: Participação percentual no total das operações de crédito da área bancária. 1994-2005*

\begin{tabular}{|c|c|c|c|c|c|}
\hline Operações de Crédito & 2001 & 2002 & 2003 & 2004 & 2005 \\
\hline Bancos Públicos ${ }^{1}$ & 24,80 & 28,60 & 32,70 & 31,30 & 30,52 \\
\hline Banco do Brasil & 14,53 & 16,17 & 20,36 & 19,36 & 18,46 \\
\hline Bancos Privados $^{2}$ & 73,60 & 69,70 & 65,10 & 66,40 & 67,21 \\
\hline Cooperativas de Crédito & 1,60 & 1,80 & 2,10 & 2,30 & 2,27 \\
\hline Total & 100,00 & 100,10 & 99,90 & 100,00 & 100,00 \\
\hline
\end{tabular}

teira de crédito ao agronegócio dentro da carteira de crédito do Banco do Brasil. Entre os produtos destinados ao agronegócio destacam-se o Programa de Geração de Emprego e Renda (Proger) e o Pronaf Rural, sendo este último destinado ao custeio da atividade dos agricultores familiares. Essas linhas de crédito, juntas, representaram $24,7 \%$ da carteira do agronegócio em 2006 (tabela 8). Os recursos utilizados pelo BB para o crédito rural têm como origem, principalmente, depósitos de poupança, recursos do Fundo de Amparo ao Trabalhador (FAT), depósitos à vista, recursos do Fundo do Centro-Oeste (FCO) e do BNDES, entre outros.

O Banco do Brasil é também o agente financeiro do Fundo Constitucional de Financiamento do Centro-Oeste (FCO) ${ }^{26}$ No ano 2006, o BB contratou 52.000 operações com recursos do FCO, em um total de R \$1,4 bilhão. Do total dessas operações, 95,3\% foram contratadas por produtores rurais. Do total dos municípios da região de cobertura do Fundo, a região Centro-Oeste, o equivalente a 98,9\% contou com pelo menos uma operação do FCO em 1996 (Relatório do Banco do Brasil, 2006).

No que diz respeito ao FAT, o BB conquistou, em 2006, a liderança na participação dos depósitos especiais do FAT, destinados a operações de crédito para geração de emprego e renda. O montante correspondeu a $\mathrm{R} \$ 7,7$ bilhões, que representou $48,5 \%$ dos recursos repassados aos bancos oficiais e lastreou diversas linhas de crédito do BB, tais como o Programa Nacional do Fortalecimento da Agricultura Familiar (Pronaf) e o Proger (Relatório do Banco do Brasil, 2006).

Por fim, um evento que merece ser mencionado, no período em foco, e que também diz respeito a essa faceta "pública" do BB, foi a criação do Ban- 


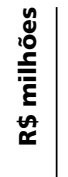

穴

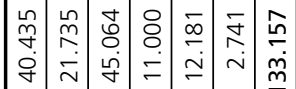

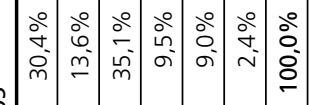

융

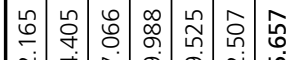

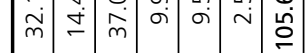

ํํำ

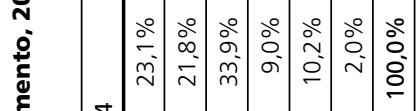

ठ্

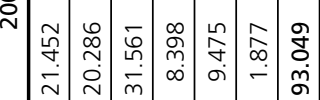

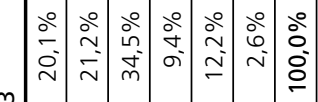

ஜ̊̀

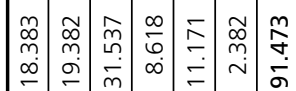

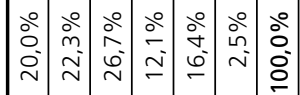

ัญ

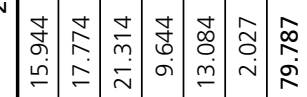

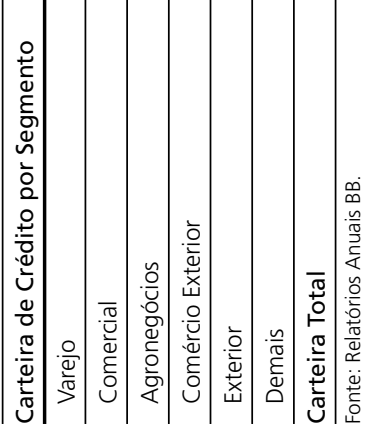

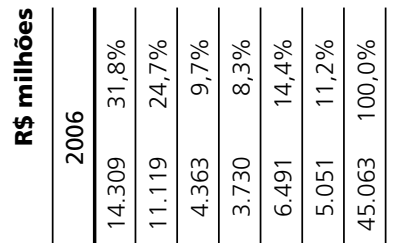

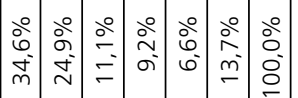

농

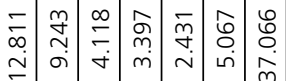

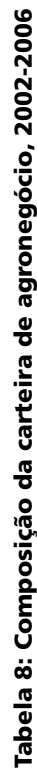

ठे

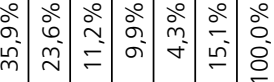

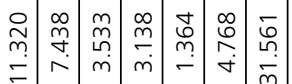

$=\wedge m m-\dot{\sigma} \bar{m}$

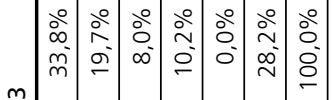

ஜे

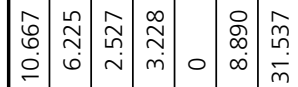

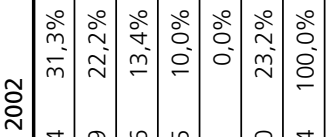

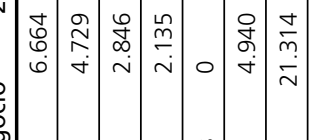
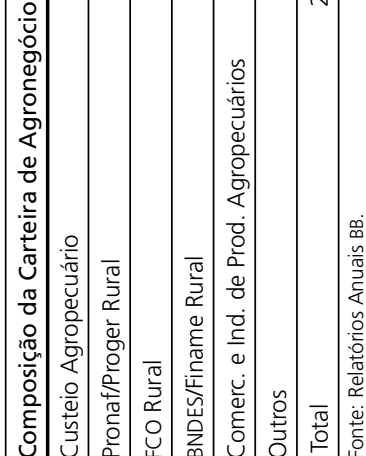
co Popular do Brasil, em um contexto político em que o governo procurou incentivar o acesso ao crédito para a população de baixa renda. Tendo iniciado suas operações em 2004, o Banco Popular nasceu como uma subsidiária do $\mathrm{BB}$ para atuar no mercado de microfinanças e atender à população até então não bancarizada - basicamente a população de baixa renda (definida, à época, como tendo renda mensal de até três salários mínimos, isto é, $\mathrm{R} \$ 720,00)$ e aqueles que se encontram no setor informal da economia.

Para atender aos seus clientes, o Banco Popular utiliza uma estrutura distinta das agências do BB, frequentadas pela clientela tradicional. Contudo, ao invés de ter agências próprias, o Banco Popular usa pontos de venda (como, por exemplo, farmácias, pequenos mercados ou papelarias), nos quais o cliente pode, por exemplo, abrir sua conta, efetuar saques, fazer pagamentos, depósitos, consultar saldos e contrair empréstimos. A ideia foi criar uma estrutura com baixo custo operacional - daí o aproveitamento de pontos de vendas já existentes, aliado à utilização da estrutura do BB para operar as transações - que permitisse a cobrança de juros abaixo do mercado, além de segmentar a clientela do crédito popular da tradicional clientela do BB.

O projeto original do Banco Popular previa que ele se tornasse uma instituição lucrativa, ainda que com resultados menores que os dos bancos tradicionais, pois seu principal objetivo seria o de promover a inclusão bancária e o acesso ao crédito. Contudo, ao apresentar prejuízos sucessivos desde a sua criação até o ano 2006 - em função de um alto grau de inadimplência na carteira de crédito nos primeiros dois anos, girando entre $20 \%$ a $25 \%$ o modelo do Banco Popular começou a ser questionado e a instituição iniciou uma reorientação em sua atuação. ${ }^{27}$ Por conta disso, em meados de 2005 implementou-se uma modificação importante no processo de concessão do crédito, que deixou de ser imediato e automático, com a exigência de um tempo mínimo de relacionamento do cliente com o Banco e a consideração de seu histórico com a instituição, bem como outros critérios para avaliar o potencial de repagamento do cliente. Ademais, o Banco Popular passou a apostar mais no microcrédito produtivo orientado, e menos no microcrédito de livre direcionamento, pois aquele tem menor inadimplência, devido a parcerias com as OSCIPs (Organizações da Sociedade Civil de Interesse Público), instituições especializadas em análise e direcionamento de crédito para comunidades produtivas. 


\section{OBSERVAÇÕES FINAIS}

As evidências empíricas apresentadas dão conta de nosso questionamento principal, a saber, se as medidas recentes e, de forma mais específica, esse movimento último de enquadramento do Banco do Brasil — bem como das demais IFPFs - às regras de Basileia apenas "reforçam" financeira e administrativamente o BB ou se, ao contrário, deslocam-no para uma atuação progressivamente afastada de sua função anterior de banco público, especialmente como banco de fomento. Os vários indicadores disponíveis para o período objeto de nossa análise, inclusive os resultados bastante positivos obtidos pelo Banco (tabela 1), mostram que o Banco do Brasil tem pautado sua conduta na busca de resultados financeiros de excelência, ainda que consiga manter uma atuação mais circunscrita de banco público em alguns setores importantes, notadamente na agricultura.

Um importante evento recente que reforça nosso ponto de vista é que, no ano 2006, foi feita uma oferta pública secundária de ações do Banco do Brasil, no valor de R \$ 2,3 bilhões. A operação marcou o ingresso do Banco do Brasil no Novo Mercado da Bovespa, o mais rigoroso segmento de listagem da Bovespa, do qual participam empresas que têm o mais elevado grau de governança corporativa - empresas que se comprometem com práticas e regras societárias mais rígidas do que as exigidas pela legislação brasileira. Com essa operação, o volume de ações do BB em circulação no mercado (free float) subiu de 6,9 para 14\%, mas deverá aumentar mais ainda, pois uma das exigências do Novo Mercado é a manutenção de ao menos $25 \%$ do capital da companhia em circulação. O cumprimento das exigências do Novo Mercado exigirá do Banco, crescentemente, resultados de excelência do ponto de vista do mercado - os quais não são, necessariamente, resultados excelentes para um banco público.

A presente discussão buscou salientar os elementos básicos da trajetória do Banco do Brasil capazes de evidenciar que houve uma mudança importante na lógica de operação do Banco e que afetou fortemente seu desempenho. Nesse sentido, é possível afirmar que o Programa de Fortalecimento das Instituições Financeiras Federais e o enquadramento progressivo do Banco do Brasil às regras de Basileia significaram uma inflexão vital em seu percurso temporal. Tais acontecimentos representaram, assim como outros igualmente importantes que definiram um rumo específico para a instituição 
(como, por exemplo, a extinção da conta-movimento, que deu o golpe de misericórdia em sua atuação como autoridade monetária), "eventos cruciais" à la Shackle, no sentido de que contribuíram para romper e mudar de forma irreversível as condições definidoras de seu contexto prévio de atuação.

\section{NOTAS}

1. O ano 1808 marcou a fundação de uma instituição bancária com o nome de Banco do Brasil, que veio a ser liquidada em 1829. Em 1853 criou-se outra instituição com o nome de Banco do Brasil, surgida de uma fusão entre o Banco Comercial do Rio de Janeiro e o Banco do Brasil de Mauá. Em 1890 nasceu o Banco da República dos Estados Unidos do Brasil, fruto da fusão do Banco Nacional do Brasil com o Banco dos Estados Unidos do Brasil. Com esse novo estabelecimento, o Banco do Brasil perdeu sua posição de liderança e, diante disso, efetuou-se sua fusão com o Banco da República. Surgiu daí o Banco da República do Brasil (conforme Banco do Brasil, 2007. História do Banco do Brasil - doravante HBB, 2007).

2. Em dezembro de 2006, o BB possuía 24,4 milhões de clientes, 15,1 mil pontos de atendimento e 82,7 mil funcionários. O volume total de ativos do Banco, em dezembro de 2005, era de R $\$ 256$ bilhões, e o total de depósitos, de R \$ 139,3 bilhões, respectivamente $16,5 \%$ e $15,4 \%$ do total do sistema bancário.

3. O maior acionista do BB é o Tesouro Nacional, com $68,7 \%$ do capital total, seguido pela Previ (Fundo de Previdência dos Funcionários do Banco do Brasil), com 11,4\% e BNDESPAR - 5,0\% (posição de dezembro de 2006). Das ações, 14,8 \% estão pulverizadas em mercado (o chamado free float) e 7,2\% são de propriedade do capital estrangeiro.

4. Esses recursos podem, de fato, lastrear a totalidade das operações - constituindo um fundo diferenciado em relação à captação de mercado e direcionado para fins específicos, em condições predeterminadas etc. - e/ou podem ser repassados pelo Tesouro a título de uma "equalização" para a instituição, cobrindo a diferença entre o custo (administrativo, tributário e de capital) da operação - no caso das operações de fomento, com taxas relativamente reduzidas - e a sua receita.

5. Também caberia apontar aqui outras ações reguladoras de mercado mais pontuais que os bancos públicos podem exercer, e que de fato já exerceram muitas vezes, como, por exemplo, o de carregar maciçamente papéis que tendem a ser rejeitados pelo mercado em momentos de maior incerteza — o que vale até mesmo para a dívida pública —, o que tende a contribuir, sobejamente, para a estabilidade do sistema como um todo.

6. Aqui também caberia uma ação de banco público em sentido contrário, isto é, não seguindo o mercado em momentos em que este estivesse eufórico, buscando disciplinar a construção daquelas estruturas financeiras excessivamente frágeis geradas endogenamente pelo mercado, conforme a análise de Minsky (1986).

7. Ao final do primeiro semestre de 1986 , do total dos empréstimos, $40 \%$ eram financiados por recursos próprios e captação no mercado (HBB, 2007). 
8. Sobre a nova estrutura de funding do BB no período, Vidotto (2002, p. 269) afirma que "o agravamento da crise fiscal impôs uma sistemática de aportes onde se acumulavam atrasos, ora cobertos no interior de cada exercício, ora de prazos mais dilatados (...) $[\mathrm{N}]$ esse sentido, as reformas fragilizaram o BB em sua estrutura financeira na medida em que promoveram o encarecimento médio de seu funding, submetendo-o a vicissitudes do mercado para atender objetivos de política econômica. As reformas, assim como a Constituição Federal de 1988, não definiram novas fontes de recursos compatíveis com o crédito à atividade agropecuária e outras 'missões'”.

9. Pelo menos no período mais recente, que é objeto desta análise.

10. A Cacex foi criada em 1953. Entre suas principais funções estavam o licenciamento de exportações e importações e o financiamento do comércio exterior brasileiro.

11. Segundo Jung (2004, p. 111-112), o governo continuou atrasando o repasse de recursos para o financiamento do setor agrícola, bem como para o financiamento de outras atividades. O Banco também teve de cumprir compromissos em nome do Estado, honrando garantias firmadas em nome do governo e empréstimos concedidos a órgãos públicos.

12. Ver BNDES - Secretaria de Assuntos Econômicos (2006).

13. A não ser que haja alguma indicação em contrário, os valores monetários apresentados neste texto referem-se a preços de dezembro de 2006.

14. Na verdade, com a queda da inflação, no segundo semestre de 1994 o Banco já apresentava prejuízos.

15. Em valores correntes.

16. A adesão do Brasil às regras de Basileia I deu-se via Resolução no 2.099 do Banco Central, de 17 de setembro de 1994, na qual se definiu a relação de 8\%. Em junho de 1997, elevou-se o nível de capital para 10\% dos ativos ponderados pelo risco (Resolução no 2.399). Em novembro do mesmo ano, subiu para $11 \%$ (Circular no 2.784). Para uma avaliação aprofundada dos Acordos de Basileia, consultar as várias contribuições em Mendonça e Andrade (2006).

17. Definiu-se nova estrutura administrativa, com a criação de unidades de negócios e unidades de suporte. As unidades de negócios cobrem as seguintes áreas: comercial, de distribuição, de governo, internacional, de mercado de capitais e investimentos, de recuperação de créditos, rural e agroindustrial, de seguridade, de varejo e de negócios. Ademais, procurou-se isolar as influências políticas sobre as operações do Banco, com a redução do poder dos representantes do governo nos conselhos de administração e fiscal (HBB, 2007).

18. Deve-se considerar, porém, que o fortalecimento dos grandes grupos do agribusiness pode ter sido uma modalidade de política pública intencional.

19. No que diz respeito à avaliação da trajetória do crédito rural, Vidotto (2002, p. 273) afirma ter havido uma redução, em termos absolutos, ao longo da década de 1990, no fluxo de recursos para o crédito rural, bem como uma progressiva redução no grau de subsídio implícito nas taxas cobradas no interior do sistema. Para ele, "a reforma do 
crédito rural dos anos 1980 não conformou um padrão alternativo de financiamento da atividade agropecuária (...) O esquema de cobertura financeira do setor pelo Estado poderia ser caracterizado primeiro pela diminuição substancial dos subsídios creditícios, segundo pela substituição das fontes orçamentárias do SNCR (Sistema Nacional de Crédito Rural)".

20. O autor refere-se aqui à tentativa de privatizar a BB-DTVM e a BB-Securities.

21. Em valores correntes.

22. Outra modificação importante para o BB foi uma mudança na estrutura de sua carteira de crédito. Houve uma redução na participação das operações de crédito rural (de $41,8 \%$ da carteira para $28,4 \%$ ) e ampliação das carteiras de varejo e comercial "com ênfase em operações massificadas automatizadas e lastreadas em recebíveis” (Banco do Brasil, Relatório Anual de 2001).

23. Conforme a tabela 1, eficiência é um indicador obtido da razão entre despesas administrativas e receitas operacionais. E o índice de cobertura é o resultado da razão entre receita de prestação de serviços e despesas de pessoal.

24. Esse crescimento foi mais do que proporcional ao crescimento da carteira de crédito nesse período, que representou cerca de $66 \%$.

25. Parte do crescimento de 2006 deveu-se a operações de renegociação com os produtores rurais.

26. O FCO foi criado pela Constituição Federal de 1988, que destinou 3\% do produto da arrecadação dos impostos sobre renda e produtos industrializados para aplicação em programas de financiamento aos setores produtivos das Regiões Norte, Nordeste e Centro-Oeste. Ao FCO cabe $20 \%$ do total desses recursos, equivalente a $0,6 \%$ do produto da arrecadação dos impostos supracitados.

27. Não há clareza quanto ao significado do prejuízo apresentado pelo Banco Popular nos primeiros anos. Pode-se considerar que os prejuízos ocorridos fossem esperados, ainda que não nessa magnitude, mas também deve-se considerar a hipótese de que o projeto inicial não previa prejuízo nem mesmo nos primeiros anos de operação.

\section{REFERÊNCIAS BIBLIOGRÁFICAS}

BANCO DO BRASIL. História do Banco do Brasil. Disponível em: [http://www.bancodobrasil. com.br], 2007. (HBB)

- Relatório do Banco do Brasil, 2006.

- Relatório Anual (vários anos).

BNDES - Secretaria de Assuntos Econômicos. Maiores lucros aumentam dividendos dos bancos públicos. Visão do Desenvolvimento, n. 16, out. 2006.

JUNG, N. L. As mudanças no Banco do Brasil na década de 1990: identificação, causas e consequências. (Dissertação de Mestrado) - Faculdade de Ciências Econômicas, UFRGS, 2004.

KEYNES, J. M. The General Theory of Employment, Interest and Money. Londres: Macmillan, 1936. 
MENDONÇA, A. R. R.; ANDRADE, R. P. DE (Orgs.). Regulação bancária e dinâmica financeira: evolução e perspectivas a partir dos acordos de Basiléia. Campinas: IE/Unicamp, 2006.

MINISTÉRIO DA FAZENDA. Fortalecimento das instituições financeiras federais. Nota Oficial, 22 jun. 2001. [http://www.fazenda.gov.br/portugues/releases/2001/r010622.asp]

MINSKY, H. P. Stabilizing an Unstable Economy. New Haven: Yale University Press, 1986.

OLIVEIRA, J. J. A gestão do crédito rural no Brasil sob a globalização financeira - o período 1995/2001. (Tese de Doutorado) - IE/Unicamp, 2003.

VIDOTTO, C. A. Banco do Brasil - Crise de uma empresa estatal do setor financeiro (1964-1992). (Dissertação de Mestrado) - IE/Unicamp, 1995.

O sistema financeiro brasileiro nos anos noventa - um balanço das mudanças estruturais. (Tese de Doutorado) - IE/Unicamp, 2002. 